\title{
PERENCANAAN LINGKUNGAN DAN BANGUNAN BERKELANJUTAN DI INDONESIA: TINJAUAN DARI ASPEK PERATURAN PERUNDANG-UNDANGAN
}

Sustainable Environment and Building Planning and Design in

Indonesia: The status of Laws and Regulations

\section{Mohd. Syarif Hidayat ${ }^{1}$}

Diterima: 18 Oktober 2016 Disetujui: 12 Desember 2016

\begin{abstract}
Abstrak: Definisi tentang bangunan hijau, pada intinya harus bersifat ramah lingkungan dan berkelanjutan mulai dari perencanaan, pelaksanaan sampai dengan pengoperasian bangunan. Dalam implementasinya tentu dibutuhkan perangkat perundang-undangan untuk menjamin pelaksanaannya. Permen KLH mengeluarkan peraturan tentang kriteria dan sertifikasi bangunan ramah lingkungan dimana isinya memiliki beberapa kesamaan dengan parameter bangunan hijau yang dikeluarkan oleh GBCI. Parameter yang dikeluarkan oleh GBCI adalah Tepat Guna Lahan, Efisiensi Energi dan Refrigeran, Konservasi Air, Sumber dan Siklus Material, Kualitas dan Kenyamanan Udara, dan Manajemen Lingkungan Binaan. Pertanyaan penelitian ini adalah apakah terdapat peraturan perundang- undangan lain yang mendukung konsep bangunan 'hijau'. Metode yang digunakan adalah deskriptif yang meninjau peraturan perundangan dari aspek-aspek bangunan hijau. Hasil penelitian menunjukkan bahwa masih banyak peraturan perundang-undangan di Indonesia belum mengakomodasi kriteria perencanaan bangunan hijau.
\end{abstract}

Kata kunci: parameter bangunan hijau, perencanaan bangunan, ramah lingkungan, berkelanjutan, peraturan perundang-undangan, Konsil Bangunan Hijau Indonesia (GBCI).

\begin{abstract}
Definitions of green buildings, in essence it should be environmentally friendly and sustainable ranging from planning, implementation to operation of the building. In the implementation of the legislation is needed to ensure its implementation. Candy MOE issued a regulation on the criteria and certification of environmentally friendly building where the content has some similarities with the green building parameters issued by GBCI. Parameter issued by GBCI is Appropriate Land, Energy Efficiency and Refrigerants, Water Conservation, Resource and Material Cycle, Quality and Comfort Air, and the Built Environment Management. This research question is whether there are other laws that support the concept of building a 'green'. The method used is descriptive review the regulations of the aspects of green building. The results showed that there are many laws and regulations in Indonesia has not accommodate green building design criteria. This could mean there are no rules or regulations already exist, but still expressed in general.
\end{abstract}

Keywords: green building parameter, building planning, environmentally friendly, sustainable, regulations, Green Building Council Indonesia (GBCI)

\footnotetext{
${ }^{1}$ Fakultas Teknik, Universitas Mercu Buana, Jalan Meruya Selatan, Kembangan, Jakarta Barat.
} 


\section{PENDAHULUAN}

Bangunan hijau bukan hanya berkonotasi/ berkaitan dengan bangunan tetapi juga lingkungan dimana bangunan itu berada. Hal ini seperti tertuang dalam pedoman Rencana Tata bangunan dan Lingkungan (RTBL, 2007). Dengan demikian maka untuk keberhasilan kinerja suatu bangunan juga ditentukan oleh kinerja lingkungannya.

Terdapat perbedaan pengertian mengenai bangunan hijau (green building) di Indonesia dan mancanegara. Dari berbagai sumber literature, bangunan hijau disejajarkan atau disetarakan dengan bangunan berkelanjutan (sustainable building) (US EPA, 2006; USGBC, 2009). Namun di Indonesia, bangunan hijau dikenal dengan istilah bangunan ramah lingkungan (environmental friendly building), yang berkonotasi bahwa bangunan harus dapat mengurangi dampaknya terhadap lingku ngan. Istilah bangunan ramah lingkungan ini digunakan oleh Kementerian Lingkungan Hidup dalam Peraturan mengenai bangunan hijau (Peraturan Menteri Lingkungan Hidup, 2007).

Berkaitan dengan definisi bangunan hijau, Badan Proteksi Lingkungan Amerika Serikat (US Environmental Protection Agency) bangunan hijau, didefinisikan sebagai sebuah perencanaan dan perancangan bangunan melalui sebuah proses yang memperhatikan lingkungan dan menggu nakan sumber daya secara efisien pada seluruh siklus hidup bangunan dari mulai pengolahan tapak, perancangan, pemba ngunan, penghunian, pemeliharaan, reno vasi dan perubuhan bangunan (US EPA, 2006). Konsep ini merupakan pengem bangan dari metoda perencanaan yang sebe lumnya yang sudah mempertimbangkan aspek ekonomi, utilitas, keandalan dan kenyamanan. Green Building juga dikenal sebagai bangunan berkelanjutan atau bangunan dengan kinerja tinggi. Di Indonesia bangunan hijau didefinisikan sebagai suatu bangunan yang menerapkan prinsip lingkungan dalam perancangan, pembangunan, pengoperasian, dan pengelolaannya dan aspek penting penanganan dampak perubahan iklim. (Peraturan Menteri KLH, 2012). Dari kedua definisi di atas, ternyata definisi dari US Green Building Council dengan Peraturan Menteri KLH memilki kemiripan walaupun pengertian awalnya sedikit berbeda.

Berkaitan dengan rincian bangunan hijau, Dewan Bangunan Hijau Amerika Serikat (USGBC, 2009), bangunan hijau memiliki 6 parameter yaitu: tapak berkelanjutan, efisiensi air, energi dan atmosfir, material dan sumber daya, kualitas udara dalam ruangan, inovasi perancangan. Di Indonesia, melalui Konsil Bangunan Hijau Indonesia (Indonesia Green Building Council) bangunan hijau dicirikan dengan enam parameter, yaitu: tepat guna lahan, efisiensi energi dan refrigeran, konservasi air, sumberdaya dan siklus material, kualitas dan kenyamanan udara, manajemen lingkungan bangunan.

Apabila diperhatikan maka dari kedua lembaga bangunan hijau ini terdapat kesamaan pada lima prinsip yang pertama, namun untuk yang keenam berbeda. Di sisi lain pemerintah melalui Kementerian Lingkungan Hidup, menetapkan parameter bangunan hijau sebagai berikut: material bangunan yang ramah lingkungan, konservasi sumber daya air, konservasi dan diversifikasi energi, bahan bukan perusak ozon, pengelolaan air limbah domestic, pemilahan sampah, kesehatan bagi penghuni bangunan, pengelolaan tapak berkelanjutan.

Apabila dibandingkan antara parameter yang disampaikan oleh Dewan Bangunan Hijau Indonesia dan Peraturan Menteri KLH, maka ini juga terdapat beberapa kesamaan, seperti tapak berkelanjutan, konservasi energi dan air serta penggunaan material ramah lingkungan. Sedangkan perbeda annya adalah dalam Permen KLH pengelo laan sampah dan sifat material yang dirinci lebih lanjut.

Dengan adanya peraturan Menteri KLH ini pelaksanaan pembangunan dengan konsep bangunan hijau di Indonesia akan lebih kuat. Namun demikian peraturan ini masih memberikan gambaran secara umum mengenai konsep bangunan hijau ini. Pertanyaannya adalah apakah ada peraturan perundang-undangan lain yang yang mendukung konsep 
bangunan hijau. Atau dalam pengertian yang lebih umum lagi apakah terdapat peraturan perundang-undangan yang memiliki filosofi ramah lingkungan dan berkelanjutan ? Penelitian ini bertujuan akan menggali lebih lanjut peraturan perundang-undangan yang memiliki pemikiran dasar ramah lingkungan dan berkelanjutan. Sehingga keberlanjutan pembangunan bangunan gedung dengan konsep bangunan hijau akan lebih terjamin.

Pertanyaan - pertanyaan yang akan diajukan dalam penelitian ini adalah sebagai berikut:

1. Selain Permen KLH, apakah terdapat peraturan perundang- undangan lain di Indonesia yang mendukung bangunan 'hijau'?

2. Aspek-aspek apa saja yang menjadi pembahasan peraturan perundangan yang bernafaskan 'green' tersebut?

3. Peraturan - peraturan apa yang belum ada apabila dilihat dari parameter bangunan 'hijau'?

4. Peraturan - peraturan apa yang sudah ada namun masih perlu dilengkapi atau diperbaiki dalam rangka penerapan prinsip bangunan 'hijau' di Indonesia?

Prinsip bangunan 'hijau' atau bangunan berkelanjutan ini penting diimplementasikan mengingat banyak masalah yang menyangkut bangunan dan lingkungan yang memerlukan penanganan serius dari pemerintah dan masyarakat. Di antara masalah tersebut adalah kekurangan pasokan energi, inefisiensi penggunaan energi dalam bangunan, kekurangan pasokan air bersih, inefisiensi penggunaan air dalam bangunan serta limbah dari bangu nan baik selama proses pembangunan mau pun penggunaan bangunan.

\section{METODOLOGI}

Penelitian ini bersifat deskriptif yang men jelaskan tentang peraturan perundangundangan yang berkaitan dengan kriteria perencanaan dan perancangan bangunan hijau.

Penelitian dilakukan dengan cara kajian mendalam terhadap parameter perencanaan dan perancangan bangunan hijau yang memiliki 5 (lima) parameter, yaitu: Tepat Guna Lahan, Efisiensi Energi dan Refrigeran, Konservasi Air, Sumber dan Siklus Material, Kualitas dan Kenyamanan Udara dan Manajemen Lingkungan Bangunan. Kajian juga dilakukan terhadap peraturan perundang-undangan di Indonesia dari mulai Undangundang (UU), Peraturan Pemerintah (PP), Peraturan Presiden (Perpres), Keputusan Presiden (Kepres), sampai Peraturan Menteri (Permen). Adapun penjelasan dari masingmasing parameter adalah sebagai berikut:

\section{Tepat Guna Lahan / Tapak Berkelanjutan}

Prinsip utama dari Tepat Guna Lahan adalah meminimalkan sistem perkotaan yang terpencar dan mengurangi pengembangan pada kawasan, habitat dan ruang terbuka hijau yang bernilai, yang diakibatkan pembangunan yang tidak efisien. Perlu didorong pembangunan dan penataan kota yang lebih kompak, serta peningkatan vitalitas kota dengan tujuan untuk mempertahankan ruang terbuka hijau (USGBC, 2009).

Aspek-aspek yang lebih rinci dari Tepat Guna Lahan adalah: Area Hijau Dasar, Pemilihan Tapak, Akses Masyarakat, Transportasi Publik, Penggunaan Sepeda, Lansekap Tapak, Iklim Mikro, manajemen Limpasan Air Hujan,

\section{Efisiensi dan Konservasi Energi}

Masalah energi dan refrigeran pada dasarnya melakukan penghematan energi dengan tujuan meminimalkan berbagai dampak terhadap lingkungan, seperti udara, air, tanah, dan sumber alam, melalui perencanaan tapak dan perancangan bangunan yang optimal, pemilihan material, dan pengukuran penghematan energi secara aktif. Dengan melakukan ini diharapkan bangunan dapat mencapai kinerja yang baik. Perlu terus 
dilakukan upaya untuk menggunakan energi yang dapat diperbarui dan sumber lain yang berdampak rendah terhadap lingkungan (USGBC, 2009). Aspek-aspek dari Energi dan Atmosfir adalah : Pengukuran Listrik, Perhitungan OTTV (Overal Thermal Transfer Value), Pengukuran Hemat Energi, Penerangan Alami, Ventilasi, Pengaruh Perubahan Iklim, Energi Terbarukan di Tapak (bonus).

\section{Konsenasi Air}

Tujuan dari efisiensi air adalah untuk melindungi siklus air alami melalui perancangan tapak dan bangunan sehingga sistem tata air yang direncanakan, paling tidak, mendekati keadaan sebelum pembangunan. Perlu diberi penekanan khusus pada penyimpanan air luapan dan serapan air pada tapak serta penyerapan kembali air tanah sehingga mendekati sistem alami. Perlu upaya-upaya untuk meminimalkan penggunaan air bersih untuk hal-hal yang tidak perlu dan tidak efisien pada tapak. Perlu terus memaksimalkan daur ulang dan penggunaan kembali air, seperti yang berasal dari tampungan air hujan, air banjir dan air kotor (USGBC, 2009). Aspek-aspek yang lebih rinci dari efisiensi Air adalah: Meteran Air, Perhitungan Air, Pengurangan Penggunaan Air, Alat Perlengkapan Sanitasi, Daur Ulang Air, Sumber Air Alternatif, Penampungan Air Hujan, Lansekap Hemat Air.

\section{Sumber Daya dan Siklus Material}

Tujuan dari parameter ini pada dasarnya bertujuan untuk meminimalkan penggunaan material konstruksi yang tidak dapat diperbaharui, dan sumber-sumber lain seperti energi dan melalui rekayasa, perancangan, perencanaan dan konstruksi yang efisien serta daur ulang dari material bangunan. Memaksimalkan penggunaan material yang telah digunakan, dengan kandungan daur ulang. Konsep ini diterapkan terutama pada aktifitas renovasi bangunan (USGBC, 2009). Aspek yang lebih rinci dari material dan sumber daya adalah : Penggunaan Refrigeran, Produk yang diproses secara ramah lingkungan, Bahan tidak merusak lapisan ozon (non Ozone Depleting Substance = ODS), Kayu Bersertifikat, Bahan Pracetak, Bahan Regional.

\section{Kesehatan dan Kenyamanan Ruangan}

Kualitas udara dalam ruangan mendorong peningkatan kenyamanan dalam bangunan, produktifitas dan kesehatan para pemakai bangunan melalui peningkatan kualitas udara ruangan, memaksimalkan cahaya alami, memberi kesempatan pemakai bangunan untuk mengendalikan sistem pencahayaan dan kenyamanan termal disesuaikan dengan kebutuhan dan preferensinya, dan meminimalisir para pemakai bangunan terhadap polutan berbahaya, seperti volatile organic compounds (VOC) yang terdapat dalam adhesif dan cat pelapis dan urea dalam produk kayu komposit (USGBC, 2009). Aspek-aspek dari Kesehatan dan Kenyamanan Ruangan adalah: Penggunaan Udara Luar, Pemantauan CO2, Pengendalian Asap Tembakau, Polutan Kimia, Pemandangan ke Luar, Kenyamanan Visual, Kenyamanan Termal dan Tingkat Akustik.

\section{Manajemen Lingkungan Bangunan}

Tujuan dari manajemen lingkungan binaan adalah agar pembangunan dapat sejalan dengan kebijakan bangunan hijau. Parameter ini berkaitan dengan lingkungan khususnya sampah/ limbah. Limbah ini terjadi pada saat dan setelah pembangunan suatu proyek. Selain itu juga berkaitan dengan pengolahan limbah organik. Pengujian terhadap bangunan khususnya berkaitan dengan peralatan dalam bangunan. Manajemen lingkungan bangunan juga berkaitan dengan pelaksanaan aspek bangunan hijau setelah selesai pembangunan, 
seperti pengendalian kualitas udara dalam bangunan dan kenyamanan pengguna (GBCI, 2011). Aspek-aspek dari Manajemen Lingkungan Bangunan adalah: Manajemen Limbah dasar, Anggota Tim Proyek, polusi dari Aktifitas pembangunan, manajemen Limbah Lanjut, Pengelolaan baik, pelaksanaan bangunan hijau

Di dalam pembahasan mengenai peraturan perundang-undangan tersebut, salah satu sumber memberikan kerangka konsep mengenai bangunan hijau sebagai berikut:

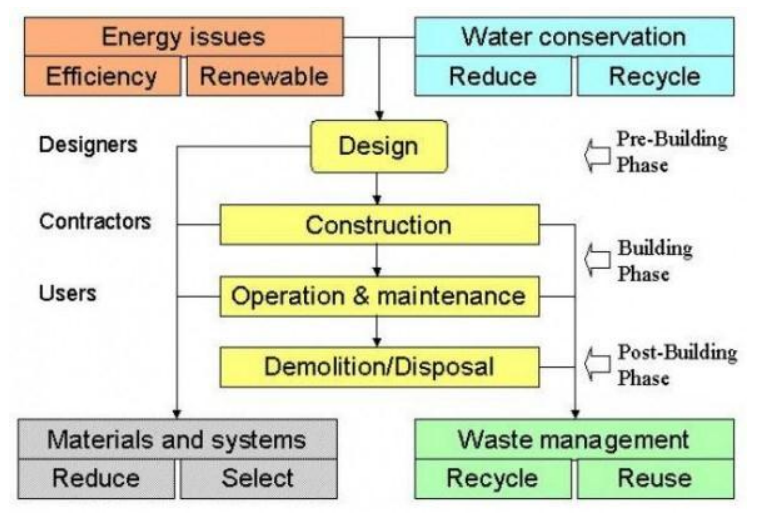

Sumber : http://www.architecturedecor.com/tag/sustainable-architecture/

\section{Gambar 1. Kerangka Konsep Bangunan Hijau}

Dalam kerangka tersebut disampaikan pokok dari bangunan hijau yang terdiri dari empat aspek yaitu energi, konservasi air, material dan sistem serta manajemen limbah. Keempat parameter tersebut diimplementasikan dalam empat tahap pembangunan yaitu tahap perancangan, pembangunan/ pelaksanaan, operasional dan pemeliharaan serta perobohan bangunan. Dalam proses ini terlibat tiga pelaku, yaitu perancangan, kontraktor dan pengguna. Dengan demikian maka ketika membahas peraturan perundangan, ada perundangan yang masuk kedalam kategori perancangan, pelaksanaan, operasional ataupun penghancuran bangunan.

Di dalam pembahasan mengenai peraturan perundang-undangan yang berkaitan dengan bangunan hijau tentunya bisa berkaitan secara langsung ataupun tidak langsung. Berkaitan langsung artinya pasal-pasal dalam peraturan tersebut mirip atau sama dengan apa yang disebutkan dalam parameter bangunan hijau. Kalau dilihat dari kedudukannya, maka tentu peraturan-perundang-undangan lebih tinggi dibanding kan dengan parameter bangunan hijau, yang berada pada tataran pelaksanaan. Oleh karena itu maka yang dibahas di sini adalah nafas atau semangat yang terdapat pera turan perundang-undangan dari parameter bangunan hijau.

\section{TEMUAN DAN KAJIAN}

\section{Temuan}

\section{Tepat Guna Lahan / Tapak Berkelanjutan}

Pembahasan mengenai parameter Tepat Guna Llahan sebenarnya sudah banyak dibahas dalam UU no 26 tentang Bangunan Gedung, bahwa bangunan harus sesuai dengan peruntukannya. Namun demikian apabila berbicara mengenai tapak berkelan jutan maka 
konteksnya sudah melebar ke arah tata ruang termasuk di dalamnya lingkungan perkotaan. Jadi pada dasarnya tapak berkelanjutan itu merupakan perenca naan tapak dalam arti makro dan mikro. Dalam arti lingkungan makro contohnya adalah lingkungan perkotaan sedangkan ling kungan mikro seperti bangunan-bangunan dan lingkungannya.

Peraturan perundang-undangan yang berkaitan dengan tepat guna lahan/ tapak berkelanjutan : Undang-undang No. 32 Tahun 2009 tentang Pengelolaan dan Perlindungan Lingkungan, Undang-undang No. 7/ Tahun 2004 tentang Sumber Daya Air, Undangundang No. 26 Tahun 2007 tentang Penataan Ruang, Undang-undang No. 28 Tahun 2002 tentang Bangunan Gedung

Dari keempat undang-undang di atas maka dua kelompok pertama merupakan peraturan yang bersifat umum, artinya belum langsung menyentuh bangunan dan atau lingkungan bangunan. Sedangkan dua peraturan lainnya berkaitan langsung dengan bangunan dan atau lingkungan bangunan.

Dalam kedua peraturan pertama di atas, terutama yang pertama sarat dengan folosofi keberlanjutan bagi suatu pembangunan. Dalam Undang-undang No. 32 tahun 2009 ini dengan jelas disebutkan mengenai pembangunan berkelanjutan. Seperti pada bagian pengertian disebutkan bahwa pembangunan berkelanjutan adalah upaya sadar dan terencana yang memadukan aspek lingkungan hidup, sosial, dan ekonomi ke dalam strategi pembangunan untuk menjamin keutuhan lingkungan hidup serta keselamatan, kemampuan, kesejahteraan, dan mutu hidup generasi masa kini dan generasi masa depan (pasal 1). Kemudian juga dijelaskan tentang asas dari perlindungan dan pengelolaan lingkungan hidup yang dilaksanakan berdasarkan asas kelestarian dan keberlanjutan (pasal 2) dimana tujuannya adalah menjamin kelangsungan kehidupan makhluk hidup dan kelestarian ekosistem; menjaga kelestarian fungsi lingkungan hidup (pasal 3).

Selain masalah pembangunan berkelanjutan juga diungkapkan mengenai pelestarian lingkungan hidup. Menurut UU ini pelestarian fungsi lingkungan hidup adalah rangkaian upaya untuk memelihara kelangsungan daya dukung dan daya tampung lingkungan hidup (pasal 1). Selanjutnya mengenai konservasi sumber daya alam disebutkan bahwa pengelolaan sumber daya alam untuk men jamin pemanfaatannya secara bijaksana ser ta kesinambungan ketersediaannya dengan tetap memelihara dan meningkatkan kualitas nilai serta keanekaragamannya (pasal 1).

Pada undang-undang yang kedua, yaitu tentang Sumber Daya Air, dinyatakan mengenai penyelenggaraan konservasi sum ber daya air. Di sini dijelaskan bahwa kon servasi sumber daya air adalah upaya memelihara keberadaan serta keberlanjutan keadaan, sifat, dan fungsi sumber daya air agar senantiasa tersedia dalam kuantitas dan kualitas yang memadai untuk memenuhi kebutuhan makhluk hidup, baik pada waktu sekarang maupun yang akan datang (pasal 1).

Dua undang-undang yang selanjutnya bersifat lebih fokus, yaitu penataan ruang dan penataan bangunan. UU Penataan Ruang lingkupnya lebih luas dibandingkan dengan UU Bangunan Gedung. Baik UU Penataan Ruang maupun bangunan Gedung keduanya menyebutkan mengenai keber lanjutan. Undang-Undang Tata Ruang meng amanatkan perlunya dilakukan penataan ruang yang dapat mengharmoniskan ling kungan alam dan lingkungan buatan, yang mampu mewujudkan keterpaduan peng gunaan sumber daya alam dan sumber daya buatan, serta yang dapat memberikan pelin dungan terhadap fungsi ruang dan pen cegahan dampak negatif terhadap lingkungan hidup akibat pemanfaatan ruang. Dalam UU ini juga disebutkan mengenai pemanfaatan ruang dalam rencana tata ruang yang harus mengembangkan penata gunaan tanah, penatagunaan air, penata gunaan udara, dan penatagunaan sumber daya alam lain. Dalam UU Tata Ruang seca ra rinci dinyatakan mengenai klasifikasi ruang terbuka hijau (RTH) yaitu Ruang terbuka hijau terdiri dari ruang terbuka hijau publik dan ruang terbuka hijau privat. (Pasal 29). Proporsi ruang terbuka hijau pada wilayah kota paling sedikit 30 (tiga puluh) persen dari luas 
wilayah kota. Dimana dari proporsi ini sebanyak 20 (dua puluh) untuk ruang terbuka hijau publik.

Selanjutnya Undang-undang tentang bangun an gedung (UUBG) lebih khusus membahas mengenai bangunan gedung. Dalam UU ini dijelaskan tentang penyelenggaraan bangun an gedung yaitu, kegi atan pembangunan yang meliputi proses perencanaan teknis dan pelaksanaan konstruksi, serta kegiatan pemanfaatan, pelestarian, dan pembong karan. Segala macam ketentuan yang terda pat dalam UU ini dikaitkan dengan UU Tata Ruang sehingga konsep keberlanjutan dapat terlaksana dalam tataran pembangunan bangunan gedung.

Dari pembahasan perundang-undangan di atas jelas semua mengarahkan pada para meter bangunan hijau, seperti kebersihan udara lingkungan dari polusi, siklus air mela lui peresapan air hujan, dan kondisi suhu udara (termal).

Dikaitkan dengan parameter rinci bangunan hijau seperti area hijau, transportasi publik dan penggunaan sepeda maka UU dan PP mengenai pengendalian lingkungan hidup banyak mengakomodasi aspek ini. Area hijau, transportasi publik, pribadi dan peng gunaan sepeda sebenarnya berkaitan dengan penjagaan kualitas udara lingkungan yang ada. Apabila penggunaan kendaraan pribadi dikurangi dengan jalan transportasi publik, maka polusi udara akan berkurang. Sedangkan area hijau dimaksudkan untuk menciptakan udara bersih lingkungan. Dengan adanya ruang terbuka hijau maka polusi akan dapat dikurangi dan udara bersih akan bertambah.

Untuk aspek siklus air yang berkaitan penja gaan sumber daya air, maka Ruang Terbuka Hijau dan Lansekap tapak berkaitan erat dengan undang-undang ini. Bahkan sebe narnya siklus air dan kualtas udara melalui ruang hijau sangat berkaitan. Bangunan ditata supaya terdapat ruang antara antara satu bangunan dengan bangunan lainnya.

Berkaitan iklim mikro, maka ruang terbuka hijau dan lansekap tapak sangat berkaitan. Dengan adanya ruang hijau maka suhu udara di sekitarnya akan menjadi lebih rendah dibandingkan dengan lingkungan yang penuh dengan pengerasan. Limpasan air hujan berkaitan dengan dua aspek ling kungan. Pertama pengaliran air sesuai dengan kapasitasnya, kedua meresapkan air untuk kepentingan dimasa akan datang.

\section{Efisiensi Energi dan Refrigeran}

Aspek yang berkaitan dengan efisiensi energi sudah menjadi perhatian dari peme rintah, yaitu sejak diundangkannya UU no.30 tentang Energi tahun 2007. Kemudian disu sul dengan PP no. 70 tahun 2009 serta yang terakhir Permen ESDM no. 14 tentang Manajemen Energi.

Salah satu pesan utama dari peraturan-peraturan adalah tentang konservasi energi. Dalam peraturan ini dinyatakan bahwa konservasi energi adalah upaya sistematis, terencana, dan terpadu guna melestarikan sumber daya energi dalam negeri serta meningkatkan efisiensi pemanfaatannya. Konservasi energi nasional menjadi tang gung jawab Pemerintah, pemerintah daerah provinsi, pemerintah, daerah kabupaten/ kota, pengusaha dan masyarakat.

Pemerintah nampaknya lebih serius mena ngani hal-hal yang berkaitan dengan peng gunaan energi dan dan dampaknya terhadap lingkungan. Hal ini terlihat dari banyaknya perundangan yang berkaitan energi, peru bahan iklim dan bahan perusak ozon. Berikut adalah peraturan perundang-unda ngan yang berkaitan dengan hal-hal tersebut: Undangundang no. 6 Tahun 1994 tentang Ratifikasi perubahan iklim, Undang-undang no. 26 Tahun 2002 tentang Bangunan Gedung, Undang-undang no 17 Tahun 2004 tentang Ratifikasi Kyoto Protokol, Undang-undang no.30 Tahun 2007 tentang Energi, Undangundang no. 31 tahun 2009 tentang Klimatologi, Peraturan Pemerintah no. 41 tahun 1999 tentang Udara Ambien, Peraturan Pemerintah no. 70 Tahun 2009 tentang Konservasi 
energi, Peraturan Pemerintah no. 79 Tahun 2014 Kebijakan Energi Nasional, Instruksi Presiden no. 13 tahun 2011 tentang penghematan energi dan air, Peraturan Menteri Perdagangan no. 24 Tahun 2006 tentang larangan Impor bahan yang mengandung Bahan Perusak Ozon, Peraturan Menteri Perindustrian no. 33 Tahun 2007 tentang larangan memproduksi bahan yang mengandung CFC, Peraturan Menteri Negara Kependudukan dan Lingkungan Hidup No. 08 Tahun 2010 tentang Sertifikasi bangunan Ramah Lingkungan, Peraturan Menteri ESDM No. 14 Tahun 2012 tentang Manajemen Energi, Peraturan Menteri ESDM No.13 Tahun 2012 tentang Penghematan Tenaga Listrik

Dari sejumlah peraturan di atas, peraturan yang paling banyak adalah energi dan manajemen sebanyak 6 buah, berkaitan dengan lingkungan global/ perubahan iklim sebanyak 5 peraturan perundangan. Pera turan mengenai bangunan gedung dan bahan perusak lingkungan sebanyak 4 buah. Hal menarik yang perlu disimak adalah bahwa peraturan perundangan yang ber kaitan dengan lingkungan dihubungkan dengan bahan perusak ozon (BPO) dan mendapat dukungan dunia internasional. Pemerintah Republik Indonesia sebagai bagian dari masyarakat internasional harus ikut meratifikasi konvensi internasional terse but demi untuk menyelamatkan bumi.

Tentang peraturan yang berkaitan dengan energi dan penghematannya terdapat dalam beberapa peraturan perundangan. Permen ESDM no. 14 menjelaskan tentang syarat-syarat yaitu pengguna sumber energi dan pengguna energi yang menggunakan sumber energi lebih dari 6000 setara ton minyak pertahun wajib melaksanakan mana jemen energi dan atau melaksanakan peng hematan energi. Kalau yang kurang dari 6000 maka dianjurkan untuk melakukan pengematan energi. Lebih lanjut peraturan ini menjelaskan pelak sanaan manajemen energi seperti menunjuk Manajer Energi; menyusun program Kon servasi Energi; melaksanakan Audit Energi secara berkala; dan lain-lain.

Untuk lebih menjamin pelaksanaan program ini maka pengguna energi dan produsen peralatan hemat energi yang melaksanakan konservasi energi diberi kemudahan dan/ atau insentif oleh Pemerintah dan/ atau pemerintah daerah. Apabila pengguna sumber energi dan pengguna energi yang tidak melaksanakan konservasi energi akan diberi disinsentif oleh Pemerintah dan/ atau pemerintah daerah.

Dalam skala yang lebih rinci Peraturan Menteri ESDM No. 31 Tahun 2005, menje laskan tentang upaya penghematan energi dalam bangunan seperti Mengatur suhu ruangan ber AC pada suhu minimal $25^{\circ} \mathrm{C}$, Mengurangi daya pencahayaan listrik ruangan maksimal 15 Watt/ m2; Mengurangi jam operasi peralatan; AC dan eskalator dihidupkan pada awal jam kerja sampai dengan 1 jam sebelum jam kerja berakhir dan; Lift dioperasikan dengan pember hentian pada setiap 2 (dua) lantai.

Dari rincian mengenai efisiensi energi dan refrigeran pada bangunan hijau maka dapat dibagi menjadi dua kategori, yaitu penghematan energi melalui energi itu sendiri serta penghematan melalui ba ngunan. Penghematan energi melalui peng gunaan energi itu sendiri meliputi Pengukuran listrik, Pengukuran hemat energi, dan Energi diperbaharui di tapak. Sedangkan penghematan energi melalui bangunan adalah Perhitungan OTTV, Penerangan alami dan dampak perubahan iklim.

Berkaitan dengan rincian hemat energi yang terdapat dalam Bangunan Hijau, maka kebanyakan parameter-parameternya sudah merupakan hal yang rinci dan hal ini biasanya sudah diatur dengan standar seperti Standar Nasional Indonesia (SNI). Contoh parameter kelompok ini adalah pengukuran listrik, perhitungan OTTV, pengukuran hemat energi, penerangan alami dan ventilasi alami. Sedangkan energi diperbaharui di tapak terdapat dalam UU mengenai Energi. Dalam UU Energi dinya takan mengenai diversifikasi, konservasi, dan intensifikasi sumber energi dan energi. Dengan demikian, maka pemerintah sudah memikirkan mengenai berkurangnya sumber daya energi pada masa datang sehingga harus mulai beralih kepada sumber energi baru dan terbarukan. 
Selanjutnya mengenai dampak perubahan iklim, dalam parameter bangunan hijau dika itkan dengan emisi CO2 yang dikandung oleh bangunan. Peraturan yang berkaitan dengan emisi CO2 adalah Keputusan DNA (Designated National Authority) pada B/277/Dep.III/LH/01/2009 yaitu memban dingkan kebutuhan energi antara design building dan base building dengan menggunakan grid emission factor (konversi antara CO2 dan energi listrik)

\section{Konsenvasi Air}

Walaupun Indonesia kaya dengan sumber daya air, namun Pemerintah tetap peduli terhadap kesinambungan salah satu sumber alam ini. Hal in diwujudkan dalam dalam beberapa Peraturan perundang-undangan yang berkaitan dengan Konservasi Air seperti: UU No. 7 Tahun 2004 tentang Sumber Daya Air, PP No. 42 tahun 2008 Pengelolaan Sumber Daya Air, Inpres No.2 Th. 2008 mengenai penghematan energi dan air, UU No. 26 tahun 2002 tentang Bangu nan Gedung, Keputusan Menteri Kesehatan No. 261 Th. 1998

Dalam peraturan di atas juga terdapat UU tentang Bangunan Gedung, dimana di dalamnya terdapat pasal-pasl yang me ngatur penggunaan air dalam bangunan. Secara umum dalam UU No. 7 Tahun 2004 tentang Sumber Daya Air dinyatakan tentang konservasi air. Dalam UU ini dinyatakan bahwa Konservasi sumber daya air adalah upaya memelihara keberadaan serta keberlanjutan keadaan, sifat, dan fungsi sumber daya air agar senantiasa tersedia dalam kuantitas dan kualitas yang memadai untuk memenuhi kebutuhan makhluk hidup, baik pada waktu sekarang maupun yang akan datang.

Berkaitan dengan rincian penghematan air dalam bangunan hijau seperti meter air, perhitungan kebutuhan air, peralatan saniter terdapat dalam SNI dan UU Bangunan gedung mengenai air dalam bangunan. Sedangkan parameter yang bermuatan penghemat air seperti daur ulang air, sumber air alternatif dan lansekap hemat air tidak diatur dalam peraturan ini. Untuk parameter pengurangan kebutuhan air sudah diatur dalam Inpres No.2 Th. 2008 mengenai penghematan energi dan air, namun per aturan ini dikhususkan pada bangunan negara.

Untuk pemanenan air hujan sudah diatur dalam UU tentang Sumber Daya Air. Pengembangan sumber daya air ( Pasal 34) meliputi: air hujan. Instalasi tangki penyimpanan air hujan kapasitas $50 \%$ dari jumlah air hujan yang jatuh di atas atap bangunan sesuai dengan kondisi intensitas curah hujan tahunan setempat menurut BMK. Pemanenan air hujan atau penam pungan air hujan sudah disinggung dalam undangundang air yaitu termasuk dalam kategori pengawetan air yaitu ditujukan untuk memelihara keberadaan dan keter sediaan air atau kuantitas air, sesuai dengan fungsi dan manfaatnya. Hal ini dilakukan dengan cara menyimpan air yang berlebihan di saat hujan untuk dapat dimanfaatkan pada waktu diperlukan dan juga mengendalikan penggunaan air tanah.

Untuk parameter lansekap hemat air tidak disinggung secara langsung dalam undang-undang karena sudah menyangkut hal teknis. Yang dimaksud dengan lansekap hemat air di sini adalah seluruh air yang digunakan untuk irigasi gedung tidak berasal dari sumber air tanah dan/ atau PDAM. Kemudian menerapkan teknologi yang inovatif untuk irigasi yang dapat mengontrol kebutuhan air untuk lansekap yang tepat, sesuai dengan kebutuhan tanaman

Berkaitan dengan Sistem Pengolahan Air kotor dan Limbah, Peraturan perundangundangan tidak mengatur secara langsung, namun berkaitan perihal sanitasi terdapat dalam UU No.28 mengenai bangunan gedung. Selanjutnya dalam PP No. 42 tahun 2008 tentang pengelolaan sumber daya air. Demikian juga hal ini terdapat dalam Keputusan Menteri Kesehatan No. 261 Th. 1998 mengatur hal-hal yang berkaitan dengan limbah. Dalam PP no. 36 tentang Bangunan Sistem pembuangan air kotor dan/atau air limbah. 


\section{Sumberdaya dan Siklus Material}

\section{Manajemen Refrigeran}

Peraturan perundang-undangan yang berka itan dengan sumber dan siklus material seca ra umum belum diakomodasi semua. Hal ini disebabkan karena material bersifat luas cakupannya. Salah satu material yang dikendalikan pemerintah adalah bahan perusak ozon (BPO) dengan salah satu bahannya adalah refrigeran. Oleh karena itu lahir beberapa peraturan perundangan yang berkaitan dengan BPO, seperti; Keppres RI No. 23 / 1992 tentang perlindungan lapisan ozon, Undang-Undang No. 17 / 2004 tentang Pemanasan Global, Peraturan Menteri Perdagangan No. 24/2006 tentang ketentuan impor BPO, Peraturan Menteri Perindustrian No 33/2007 (larangan produksi BPO dan barang yang menggunakan BPO, Peraturan Menteri Kependudukan Lingkungan Hidup (KLH) No. 2/2007 mengenai teknisi AC.

Lapisan ozon sangat bermanfaat bagi perlin dungan kehidupan di bumi karena dapat melestarikan lingkungan hidup, melindungi kesehatan manusia, kehidupan hewan dan tumbuh-tumbuhan, serta mencegah kerusa kan atas benda-benda berharga dan ber sejarah. Oleh karena itu perusakan dan penipisan lapisan ozon yang disebabkan oleh zat-zat perusak ozon (ozone depleting substances) akan sangat membahayakan kelestarian kehidupan di bumi. Maka, Indonesia sebagai anggota masyarakat international ikut aktif di dalam kegiatan bersama yang bertujuan mencegah perusakan dan penipisan lapisan ozon tersebut.

Seperti yang sudah dijelaskan terdahulu, Pemerintah peduli terhadap pencemaran lingkungan yang disebabkan oleh pema kaian bahan tertentu, seperti refrigeran. Peraturan berkenaan dengan manajemen refrigeran adalah Peraturan Menteri (Permen) Perindustrian No. 33/M-Ind/Per/4/2007 tentang Bahan Perusak Lapisan Ozon (BPO). Dalam Permen ini dinyatakan bahwa BPO adalah senyawa kimia yang berpotensi dapat bereaksi dengan molekul ozon di lapisan stratosfir. BPO biasanya digunakan pada produksi mesin pengatur suhu udara (Air Condi tioning) yang digunakan dalam ruangan dan kendaraan bermotor; lemari es tipe rumah tangga; dan alat pemadam api.

Selain itu, refrigeran diatur dalam Peraturan Menteri Negara (Permen) Lingkungan Hidup No. 02/ 2007 tentang pelaksanaan retrofit pada system tata Udara bangunan. Beberapa standar yang digunakan dalam retrofit ini adalah a. SNI 06-6500-2000 Refrigeran: Pemakaian pada instalasi tetap; atau b. SNI 06-6501.1-2000 Refrigeran Kelompok A3: Keamanan pengisian, penyim panan, dan transportasi dan SNI 06-6501.2-2000 Refrigeran Kelompok A3 : Pemakaian pada mesin tata udara kendaraan bermotor. Kemudian mengenai pelaksanaan retrofit itu sendiri ditentukan hal-hal seperti tidak melepas refrigeran jenis $\mathrm{CFC}$ dan $\mathrm{HCFC}$ ke atmosfir; tidak mengganti refrigeran non $\mathrm{CFC}$ dengan refrigeran CFC; dan pema kaian refrigeran pengganti mengacu pada SNI 06-6500-2000. Bahan refrigeran, bahan yang diproses secara ramah lingkungan serta bahan yang tidak merusak ozon saling berkaitan.

Aspek rinci dari sumber dan siklus material adalah: Bahan refrigerant, Penggunaan kem bali bangunan dan material. Bahan diproses secara ramah lingkungan, Bahan tidak meru sak ozon (non ODS Product), Kayu ber sertfikat, Bahan pracetak dan Bahan regional

Parameter material yang terdapat dalam bangunan hijau dapat dibagi tiga, yaitu material/ bahan yang berdampak terhadap atmosfir bumi (ozon), bahan bangunan dan pengolahan material. Untuk material yang berdampak terhadap lingkungan sudah diatur oleh pemerintah dalam beberapa peraturan perundang-undangan. Sedangkan untuk bahan bangunan tidak secara khusus diatur karena sudah spesifik sifatnya. Seperti kayu bersertifikat, bahan diproses secara ramah lingkungan, penggunaan kembali material . 


\section{Kualitas dan Kenyamanan Udara}

Peraturan perundangan yang berkaitan dengan kualitas dan kenyamanan udara sudah cukup banyak mendapat perhatian dari pemerintah. Hal ini dapat dilihat dari peraturan perundang-undangan dari yang sifatnya umum seperti bangunan gedung sampai dengan peraturan yang sifatnya khusus seperti peraturan menteri kesehatan.

Peraturan perundang-undangan yang ber kaitan dengan kualitas udara dan Kenya manan udara adalah : UU No. 36 Th.2009 tentang Kesehatan, PP No. 50 Th 2012 tentang penerapan Manajemen Keselamatan dan Kesehatan Kerja, UU No.28, Th. 2002 tentang bangunan gedung, PP No.36. tentang bangunan gedung Berkaitan dengan Persyaratan Kesehatan, PP no. 41 tahun 1999 tentang pengendalian pencemaran udara, Permenaker No. 13 Th. 2011 Ambang batas Fisika dan Kimia Tempat Kerja, Keputusan Menaker No. 51 Th. 1999 tentang Ambang Fisika lingkungan Kerja, Keputusan Menkes No. 14052002 Persyaratan Kesehatan Lingkungan Kerja perkantoran dan Industri, Keputusan menkes No.261 Th.1998 Kesehatan Lingkungan Kerja

Namun demikian masalah kualitas udara secara khusus, seperti dalam UU bangunan gedung yang ada adalah persyaratan kesehatan dalam bangunan. Persyaratan kesehatan bangunan gedung meliputi per syaratan sistem penghawaan, pencahayaan, sanitasi, dan penggunaan bahan bangunan gedung. Kenyamanan bangunan gedung meliputi kenyamanan ruang gerak dan hubungan antarruang, kondisi udara dalam ruang, pandangan serta tingkat getaran dan kebisingan.

Dalam undang-undang yang lain, Peme rintah menggalakkan upaya kesehatan ling kungan yang ditujukan untuk mewujudkan kualitas lingkungan yang sehat, baik fisik, kimia, biologi, maupun sosial yang memung kinkan setiap orang mencapai derajat kese hatan yang setinggi-tingginya. Lingkungan ini mencakup lingkungan permukiman, tempat kerja, tempat rekreasi, serta tempat dan fasilitas umum. Lingkungan sehat ini bebas dari gangguan yang menimbulkan gangguan kesehatan, seperti limbah cair, padat dan gas. (pasal 163) UU Kesehatan No. 36 Tahun 2009

Untuk lingkup ruang kerja, Pemerintah berusaha untuk melindungi pekerja agar hidup sehat dan terbebas dari gangguan kesehatan serta pengaruh buruk yang diakibatkan oleh pekerjaan. Upaya kesehatan kerja ini meliputi pekerja di sektor formal dan informal. Upaya kesehatan kerja juga berlaku bagi setiap orang selain pekerja yang berada di lingkungan tempat kerja. Pemerintah menetapkan standar bahwa setiap karyawan mendapatkan ruang udara minimal $10 \mathrm{~m}^{3} /$ karyawan.

Dari keseluruhan peraturan pemerintah sudah mengatur berbagai hal yang berkaitan dengan kualitas udara dan kenyamanan seperti pengaturan mengenai sistem ven tilasi atau pengudaraan dalam bangunan. Sistem ini merupakan kebutuhan sirkulasi dan pertukaran udara yang harus disediakan pada bangunan gedung melalui bukaan dan/ atau ventilasi alami dan/ atau ventilasi buatan. Ventilasi alami harus memenuhi ketentuan bukaan permanen, kisi-kisi pada pintu dan jendela, sarana lain yang dapat dibuka dan/atau dapat berasal dari ruangan yang bersebelahan untuk memberikan sirkulasi udara yang sehat. Ventilasi me kanik/ buatan harus disediakan jika ventilasi alami tidak dapat memenuhi syarat. prinsip penghematan energi dalam bangunan gedung. Pemerintah menetapkan luas jendela, kisi-kisi atau dinding gelas kaca untuk masuknya cahaya minimal 1/6 kali luas lantai.

Selain penghawaan juga diatur mengenai keadaan termal dalam bangunan. Seperti pada Kepmenkes 1405 Tahun 2002 dan Permen ESDM 2005. Dalam Permen ESDM perencanaan kondisi termal ruangan secara umum ditetapkan pada suhu $25^{\circ} \mathrm{C}$ dan kelembaban relatif $60 \%$. Pada Kepmenkes ditetapkan rentang suhu yang agak jauh yaitu antara $18-28{ }^{\circ} \mathrm{C}$, dengan kelembaban : $40 \%-60 \%$. 
Pemerintah juga mengatur tentang keber sihan udara dalam ruangan dari unsurunsur yang membahayakan kesehatan, seperti de bu dan asbes. Kenyamanan suara (kebi singan) juga, kenyamanan pandangan dari luar maupun dalam bangunan, ini dikaitkan dengan bukaan, Penggunaan bahan bangunan gedung harus aman bagi kesehatan pengguna bangunan gedung dan tidak menimbulkan dampak negatif terhadap lingkungan.

Dengan demikian maka parameter yang ditetapkan dalam bangunan hijau seperti Aspek-aspek dari Kualitas Udara dalam ruangan adalah: Kinerja Minimum Kualitas Udara Ruangan. Pengendalian Asap Tembakau, Sistem Ventilasi dalam Bangunan, Manajemen Kualitas Udara, Material Emisi Rendah, Sistem Pengen dalian dalam Bangunan, Kenyamanan termal dan Pencahayaan Alami. Secara umum sudah ada. Kalaupun tidak ada termasuk kedalam kategori peraturan yang lebih rinci.

\section{Manajemen Lingkungan Bangunan}

\section{Manajemen Limbah Dasar}

Peraturan pemerintah yang berkaitan dengan Manajemen Lingkungan Binaan sebagian sudah ada, khususnya berkaitan dengan pengelolaan dan pengolahan limbah/ sampah. Berikut adalah perundang-undangan yang berkaitan dengan sampah: UU No. 18 Th. 2008 tentang Pengelolaan Sampah, PP No 81 Th 2012 tentang Pengelolaan Sampah Rumah Tangga dan Sampah Sejenis Sampah Rumah Tangga, PP Nomor 101 Tahun 2014 tentang pengelolaan Limbah Bahan Berbahaya dan Beracun.

Namun untuk aspek lain seperti masalah tim proyek bangunan hijau, pelaksanaan bangunan hijau dan survey pengguna tidak ada karena sudah bersifat detail.

\section{PEMBAHASAN}

\section{Tapak Berkelanjutan}

Peraturan yang berkaitan dengan tapak berkelanjutan terdapat dalam UU No.28, PP No. 36, PP No.42, Permen PU No. 05/PRT/M/2008.dan Permendagri No.1 th. 2007.

Dari peraturan perundang-undangan yang berkaitan dengan tapak berkelanjutan, dapat dilihat bahwa secara umum pasal-pasalnya sudah menyatakan secara khusus kriteria perencanaan bangunan hijau. Semangat yang paling nyata terdapat pada aspek transportasi alternatif, dimana terdapat kesinambungan dari mulai Undang-undang tentang energi sampai kepada Peraturan presiden mengenai diversifikasi energi dan penggunaannya pada aspek transportasi. Demikian juga halnya dengan peraturan perundangan yang berkaitan dengan tata guna lahan sampai dengan KDB serta KLB dijelaskan secara rinci dalam peraturannya.

Yang masih umum adalah peraturan yang berkaitan denga pemanasan suhu udara kota serta pengendaliannya.

\section{Efisiensi Air}

Peraturan yang berkaitan dengan efisiensi air terdapat dalam UU No.7, dan PP No. 42. Peraturan perundang-undangan berkaitan dengan efisiensi air sebenarnya sudah cukup baik dan lengkap namun belum menyentuh aspek yang lebih mendetail, seperti sistem pengolahan air kotor, lansekap yang hemat. Kemudian undang-undang dan peraturan pemerintah ini memang mengatur hal yang lebih umum belum mengatur hal-hal yang menyangkut penggunaan air dalam bangunan, proses konstruksi ataupun yang lainnya. 
Dengan adanya Inpres No.2 tahun 2008 sebenarnya sudah cukup melengkapi dari segi peraturan, sehingga nantinya tinggal diturunkan peraturan yang lebih rinci lagi.

\section{Efisiensi Energi}

Peraturan yang berkaitan dengan tapak berkelanjutan terdapat dalam UU No.30, PP No. 70, Perpres No. 5, Inpres No.2, Permenin No.33 Permen LH No.2. dan Permen ESDM No.31. Dengan adanya Peraturan Pemerintah No. 70 tahun 2009 sebenarnya Pemerintah sudah menyadari akan pentingnya konser vasi energi karena hal ini akan sangat berpe ngaruh terhadap jalannya roda pemba ngunan. Bahkan PP ini sendiri sudah memberikan isyarat untuk membentuk mana jer energi dalam bangunan. Sehingga penge lolaan energi dalam bangunan betul-betul dapat terkontrol. Sangat perlu sosialisasi PP ini kepada masyarakat, mengingat PP No. 36 tentang Bangunan Gedung sangat minim menyentuh masalah energi dalam bangu nan. Berkaitan dengan manajemen refrige ran, Permeneg LH sebenarnya sudah cukup jadi payung hukum untuk mengatur hal-hal yang berkaitan dengan penggantian refrige ran yang masih mengandung CFC. Namun demikian sekali lagi lagi perlu terus sosia lisasi kepada masyarakat mengenai hal ini mengingat penggunaan CFC, khususnya pada sistem tata udara sudah cukup lama.

\section{Material dan Sumber Daya}

Peraturan yang berkaitan dengan material dan sumber daya terdapat dalam UU No.18, Perpres No.54. Permenhut No..

Nampaknya peraturan perundang-undangan yang berkaitan dengan material dan sumber daya kurang atau belum begitu populer, karena aspek-aspek yang terdapat dalam parameter ini lebih mengarah kepada renovasi bangunan. Walaupun demikian sebenarnya pekerjaan renovasi ini bukannya tidak ada, namun prosentasenya tidak seban ding dengan pembangunan gedung baru.

Aspek-aspek yang berkaitan dengan limbah/ sampah diatur dalam Undang-undang Nomor 18 Tahun 2008 tentang Pengelolaan Sampah. Undang-undang ini lebih mengarah kepada pengelolaan sampah/ limbah dalam konteks barang yang sudah dibuang, bukan/ belum mengatur aspek limbah dalam kaitannya dengan pemba ngunan.

\section{Kualitas Udara dalam Ruangan}

Peraturan yang berkaitan dengan kualitas terdapat dalam UU No.28, PP No. 36, Permen ESDM No.31. Dalam UU No 28 dan PP No.36 aspek kuali tas udara dalam ruangan disebutkan dalam pasal mengenai persyaratan kenyamanan dan persyaratan mengenai ventilasi dalam bangunan gedung, walaupun masih umum. Sedangkan dalam Permen ESDM sudah disebutkan mengenai suhu udara dalam bangunan yang menggunakan sistem tata udara (AC). Memang dalam peraturan ESDM ini tidak dinyatakan tentang suhu nyaman, namun dikaitkan dengan suhu yang hemat dari segi energi.

\section{KESIMPULAN}

Dari hasil pembahasan di atas dapat disimpulkan bahwa secara umum peraturan perundangan yang berkaitan dengan bangunan hijau di Indonesia sudah tersedia. Namun demikian peraturan tersebut masih banyak yang belum lengkap, seperti pembahasan masalah energi dalam bangunan dan material serta sumber daya. Pembahasan energi dalam bangunan seperti dalam UU No.28 masih kurang dan dalam peraturan-perundangan lainnya. Ke depan diharapkan Pemerintah dapat mengadakan dan/ atau melengkapi peraturan perundangan yang belum tersedia atau masih dinyatakan secara umum. 


\section{UCAPAN TERIMAKASIH}

Ucapan terimakasih disampaikan kepada Pemerintah DKI Jakarta yang telah mem berikan grant proyek penelitian mengenai penerapan bangunan hijau di Jakarta.

\section{DAFTAR PUSTAKA}

Instruksi Presiden Republik Indonesia Nomor 2 Tahun 2008 tentang Penghe matan Energi dan Air.

Instruksi Presiden Republik Indonesia Nomor 1 Tahun 2008 tentang Penye diaan dan Pemanfaatan Bahan Bakar Nabati (Biofuel) sebagai bahan bakar lain.

Peraturan Menteri Perindustrian Republik Indonesia No. 33/M-Ind/Per/4/2007 Tentang Larangan Memproduksi Bahan Perusak Lapisan Ozon serta memproduksi barang yang menggunakan Bahan Perusak Lapisan Ozon.

Peraturan Menteri Pekerjaan Umum Nomor 6 Tahun 2007 tentang Rencana Tata Bangunan dan Lingkungan;

Peraturan Menteri Pekerjaan Umum Nomor 6 Tahun 2007 tentang Pedoman Peme liharaan dan Perawatan Bangunan Gedung

Peraturan Menteri Pekerjaan Umum Nomor 5/PRT/M/ 2008 tentang Pedoman Penyediaan dan Pemanfaatan Ruang Ter buka Hijau di Kawasan Perkotaan

Peraturan Menteri Pekerjaan Umum Nomor 5 Th. 2008 tentang Ruang Terbuka Hijau;

Peraturan Menteri Dalam Negeri Nomor 7 Tahun 2007 tentang Penataan Ruang Terbuka Hijau di Kawasan Perkotaan

Peraturan Menteri Lingkungan Hidup Nomor 2 Tahun 2007 tentang Pedoman Teknis dan Persyaratan Kompetensi Pelaksa naan Retrofit dan Recycle pada Sistem Refrigerasi

Peraturan Pemerintah Republik Indonesia Nomor 47 Th. 1997 tentang Tata Ruang Nasional;

Peraturan Pemerintah Republik Indonesia Nomor 70 Th. 2009 tentang Konservasi Energi

Peraturan Pemerintah Republik Indonesia Nomor 42 Th. 2006 tentang Pengelolaan Sumber Daya Air

Peraturan Presiden Republik Indonesia Nomor 5 Th. 2006 tentang Kebijakan Energi Nasional

Peraturan Presiden Republik Indonesia Nomor 54 Th. 2010 tentang Pengadaan Barang dan Jasa Pemerintah

Peraturan Pemerintah Republik Indonesia Nomor 36 Tahun 2005 tentang Bangunan Gedung;

Peraturan Pemerintah Republik Indonesia Nomor 81 Tahun 2012 tentang Penge lolaan Sampah Rumah Tangga dan Sampah Sejenis Sampah Rumah Tangga.

Peraturan Menteri PU 30/PRT/M/2006 mengenai Pedoman Teknis Fasilitas dan Aksessibilitas pada Bangunan Gedung dan Lingkungan.

Peraturan Menteri PU No. 5/PRT/M/2008 mengenai Ruang Terbuka Hijau (RTH) B/277/ Dep.III/LH/01/2009.

Peraturan Menteri PU No. 06/PRT/M/2007 tentang Pedoman Umum Rencana Tata Bangunan dan Lingkungan

Syarif Hidayat, M. (2009). Konsep Penera pan Green Building di Jakarta. Biro Kependuduk an dan Lingkungan Hidup DKI Jakarta. Laporan Akhir Proyek.United States Green Building Council (USBGC) (2009). Leadership in Energy and Environmental Design.

Undang-undang Republik Indonesia Nomor 28 Tahun 2002 tentang Bangunan Gedung

Undang-undang Republik Indonesia Nomor 18 Tahun 2008 tentang Pengelolaan Sampah

Undang-undang Republik Indonesia Nomor 26 Tahun 2007 tentang Tata Ruang;

Undang-undang Republik Indonesia Nomor 30 Tahun 2007 tentang Energi

Undang-undang Republik Indonesia Nomor 32 Tahun 2009 tentang Perlindungan dan Pengelolaan Lingkungan Hidup;

Undang-undang Republik Indonesia Nomor 7 Tahun 2004 tentang Sumber Daya Air;

Undang-Undang Republik Indonesia Nomor 28 tahun 2002 tentang Bangunan Gedung

http://archive.epa.gov/greenbuilding/web/html/. Diunduh 18 Oktober 2015 